\title{
SHARING THE WEALTH: THE EFFECT OF SIBLINGS ON ADULTS' WEALTH OWNERSHIP*
}

\author{
LISA A. KEISTER
}

\begin{abstract}
Inequality in wealth has been well-documented, but its causes remain uncertain. Family processes in childhood are likely to shape adults' wealth accumulation, but these factors have attracted little attention. I argue that family size matters: children from larger families accumulate less wealth than do those from smaller families. Siblings dilute parents' finite financial resources and nonmaterial resources, such as time. This diminishment of resources reduces educational attainment, inter vivos transfers, and inheritance. Reduced educational attainment and transfers alter financial behavior; saving; and, ultimately, adults'wealth. I demonstrate that sibship size is associated with lower overall wealth in adulthood and that parents' resources and education, respondent's education, financial transfers, and financial behavior all mitigate the effect of siblings. Sibship size also reduces the likelihood of receiving a trust account or an inheritance and decreases home- and stock ownership. The findings provide important insights into early family processes that shape wealth accumulation and inequality.
\end{abstract}

nequalities in wealth ownership have grown dramatically in recent years. Although basic facts about the distribution of wealth are well-known, understanding of the processes that create these inequalities is limited. Wealth, or net worth, is the value of total personal assets less debts. From the 1960s to the 1990s, the total wealth owned by Americans as homes, real estate, stocks, and other financial assets increased from $\$ 7.8$ trillion to $\$ 23.5$ trillion (Keister 2000b). ${ }^{1}$ Between 1989 and 1998, the median net worth of households increased more than $20 \%$, and the number of billionaires in the Forbes 400 rose from 85 to 267 (Kennickell 2000). Yet in the same period, the proportion of net worth owned by the top $1 \%$ of owners of wealth rose from $30 \%$ to more than $34 \%$, and the proportion of net worth owned by those in the bottom $90 \%$ declined from $33 \%$ to just over $30 \%$ (Wolff 1998). The implications of this severe and growing inequality are apparent when the advantages of owning wealth are considered. Wealth provides current-use value (as in homeownership), generates more wealth when it is invested, provides a buffer during financial emergencies, and can be passed on to future generations. Moreover, it provides its owner with political power, educational and occupational opportunities, and social advantages that cumulate both within and across generations.

Recent research has demonstrated clear inequalities in wealth ownership, but the reasons for the differences remain uncertain (Conley 1999; Keister 2000a; Oliver and Shapiro 1995). Inheritance accounts for a significant proportion of wealth inequality, but intergenerational transfers do not explain even the majority of differences in the wealth owned across families (Davies 1982). Race, investment behavior, and differences among cohorts also explain some variation in wealth ownership, but unexplained variation in

*Lisa A. Keister, Department of Sociology, The Ohio State University, 300 Bricker Hall, 190 North Oval Mall, Columbus, OH 43210; E-mail: Keister.7@osu.edu. I am grateful for comments from Doug Downey, Guang Guo, Randy Hodson, Jim Moody, Jay Zagorsky, and the participants at the Jerome Levy Economics Institute's Conference on Saving, Intergenerational Transfers, and the Distribution of Wealth. Emily Click, Benjamin Cornwell, and Claire Yang provided excellent research assistance. Grants from the American Sociological Association and from Ohio State University supported the research.

1. All dollar values are in 2000 dollars, converted using the Consumer Price Index (CPI). 
wealth accumulation remains high (Davies and Shorrocks 1999; Keister and Moller 2000; Spilerman 2000). Research on wealth ownership has often referred to the importance of family processes in childhood that shape adults' wealth accumulation but has not directly explored these relationships. In particular, mention of the importance of siblings and family size is common, but researchers have not moved beyond relatively casual references to childhood family processes in understanding wealth in adulthood, partly because, until recently, longitudinal data on wealth ownership have been virtually nonexistent, preventing systematic, direct observation of links between childhood processes and wealth in adulthood.

Yet there is reason to believe that family size in childhood, in particular, contributes in important ways to adults' wealth accumulation. Social scientists have shown that the family structure in childhood shapes adults' educational attainment, occupation, and poverty (Biblarz and Raftery 1993; Biblarz, Raftery, and Bucur 1997; Eggebeen and Lichter 1991; Hao 1996). The negative effect that family size has on adults' educational performance, in particular, has been well-established (Downey 1995; McLanahan 1985; Sandefur and Wells 1999). This relationship is largely attributable to the dilution of resources that occurs as families grow (Downey 1995; Thomson, Hanson, and McLanahan 1994). Parents have finite material and nonmaterial resources, and additional siblings dilute the amount that can be devoted to each child. As family size increases, each child enjoys a smaller proportion of the financial resources that are devoted to education and other childhood activities, and inheritances are spread more thinly when there is money to be transferred across generations. Likewise, the nonmaterial resources (e.g., time and energy) that parents devote to their children are diluted in larger families. These processes likely alter the resources available to children as they start accumulating wealth, and they are likely to have a negative effect on the manner and rate at which wealth is accumulated over the entire life cycle.

My objective in this article is to explore the relationship between family size in childhood and adults' wealth-accumulation patterns. I propose that siblings reduce the material and nonmaterial resources available for each child in a family and that this diminishment of resources reduces educational attainment and direct intergenerational financial transfers. Education and direct financial transfers, in turn, shape financial decision making and wealth accumulation. Education raises adults' wealth ownership in a number of ways, such as by improving financial decision making and increasing the trajectory along which assets are accumulated. Similarly, receiving a trust fund or an inheritance can facilitate early investment in financial assets, increase the likelihood of stock- or homeownership, and thus drastically increase the lifelong accumulation of wealth. Those from larger families enjoy fewer of these advantages and accumulate less wealth as a result. In this study, I developed a theoretical model that incorporates these ideas and used the National Longitudinal Survey of Youth, 1979 cohort (hereafter NLS-Y79) to model these processes and to test these proposals empirically.

\section{SIBLINGS AND WEALTH OWNERSHIP}

The literature on family structure has documented a strong link between sibship size (number of siblings) and well-being in adulthood. As family structure changes, finite family resources can be applied more generously or less generously to achieve individual and family objectives. As families grow, parents have fewer resources to invest in each child, and each child thus fares worse, both immediately and over time. Additional siblings dilute three critical resources: material resources, opportunities, and parental attention and intervention (Blake 1981; Hill and Stafford 1978; Stafford 1996). The negative effect of family size on the availability of material resources is relatively direct, and the effect on the child is evidenced both immediately and over time (Blake 1981; Teachman 1987). Larger families have fewer resources available for education, home improvement, books 
Figure 1. Relationship Between the Number of Siblings and Wealth in Adulthood

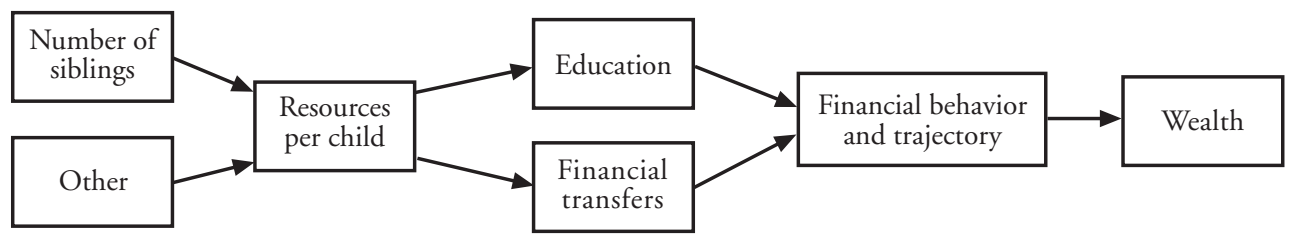

and newspapers, dance and music lessons, foreign travel, and other experiences that contribute to intellectual development (Blake 1989). Similarly, nonmaterial resources are diluted in larger families. That is, parental involvement, encouragement, intervention, and opportunities to engage the world are all vital to well-being, and these are less available to children in larger families than to those in smaller families.

For many of the same reasons that the dilution of material and nonmaterial resources in large families reduces other measures of well-being, family size is likely to decrease wealth in adulthood. There are two primary mechanisms by which sibship size and wealth in adulthood are likely to be related. First, as family size increases, there are fewer resources, both material and nonmaterial, available during childhood to enhance children's intellectual development and education. Family size reduces financial resources that would allow children to attend higher-quality schools, have access to educational materials and experiences, and enhance other educational opportunities. Similarly, family size reduces nonmaterial resources - such as parents' time, energy, and encouragement - which is also likely to diminish educational attainment. There is also evidence that the time that parents spend teaching their children to save money shapes the children's own saving behavior in adulthood. Family size is also likely to lessen this type of informal education and reduce wealth in adulthood. Second, family size reduces direct transfers of financial resources from parents to children as inter vivos (during life) transfers and inheritance. Additional children diminish resources during childhood and reduce the amount that each receives later in life. Figure 1 illustrates these relationships, and I discuss each mechanism next.

\section{FAMILY RESOURCES, EDUCATION, AND WEALTH IN ADULTHOOD}

The first mechanism through which siblings likely decrease wealth in adulthood is through education, as depicted in Figure 1. There is little doubt that material resources can improve quality of life and well-being, and one critical mechanism by which they do so is greater educational attainment. Financial resources improve educational opportunities directly and increase the availability of educational resources that improve educational attainment indirectly. Young children are able to attend higher-quality elementary and secondary schools when their parents can afford to pay the tuition. Older children are more likely to attend college, to attend elite colleges or universities, and to continue on to graduate school when their parents have sufficient resources. Financial resources also increase access to newspapers and books; computers; music and dance lessons; foreign travel; and other educational experiences, such as theater performances and museum trips (Blake 1989; Downey 1995). These experiences improve children's intellectual development and ultimately enhance educational attainment indirectly. ${ }^{2}$

2. Some have questioned this claim (e.g., Guo and VanWey 1999), but most previous research has found a strong connection between material resources and intellectual development (Downey et al. 1999). 
Family size also reduces the nonmaterial resources that affect children's educational attainment (Blake 1981, 1989). In larger families, the time that parents have available to assist children with homework, to create educational opportunities, to encourage their children, and otherwise to nurture and provide positive reinforcement is reduced. Similarly, when more children compete for attention, parents have less time to intervene when any one child is rebellious or delinquent, or otherwise gets into trouble. Likewise, children's opportunities to engage the world, that is, to interact with others and to become involved in meaningful activities that feed into later life outcomes, can be decreased in larger families. Researchers have shown that these nonmaterial resources are critical for children's development and can contribute significantly to attainment in adulthood. In their absence, attainment is likely to be reduced (Blake 1981).

Educational attainment, in turn, is directly related to wealth in adulthood for a number of reasons (Keister 2000b; Oliver and Shapiro 1995; Wolff 1998). First, education improves financial decision making. At all income levels, those who have completed more education save more, assume less debt, and make decisions regarding investments that yield larger overall portfolios. In addition, those with more education are likely to begin saving earlier in life, which allows them to accumulate assets more rapidly throughout their careers and into retirement. Investing in high-risk, high-return financial assets, such as stocks, for example, as opposed to relatively conservative instruments, such as certificates of deposit, can have dramatic effects on the total wealth accumulated over the life course (Keister 2000a). Likewise, the timing and ordering of financial decisions can shape wealth accumulation in important ways. Beginning to save in early adulthood can have significant advantages over postponing saving until later. Because a degree of path dependence is built into saving and consumption decisions, people tend to follow paths through their lives that influence, in important ways, the amount of wealth they accumulate over time. For example, a traditional trajectory may involve first buying a house and then investing in financial assets later in life. In contrast, investing in financial assets early is likely to increase total accumulation across the life course because the returns on these assets tend to be relatively high and compounding can create a sizable portfolio with time. A positive early-saving trajectory also tends to provide somewhat of a buffer against financial emergencies and economic downturns that could otherwise create a crisis and prevent additional accumulation. Finally, education can lead to important social contacts who can offer information, assistance, and referrals to persons who can provide important benefits. Social contacts may also provide direct assistance, such as capital for starting a business, making an initial financial investment, or making a down payment on a home.

Informal education about saving is also an important mechanism. Knowledge of the importance of saving, avenues available for saving, and strategies for saving is at least partly gained through exposure to parents' savings behavior (Chiteji and Stafford 1999). Because additional siblings reduce parents' savings, children are less likely to be exposed to investment options and saving in general. In large families, parents also have less time to devote to teaching their children deliberately about saving. A more abstract, but perhaps even more important, component of this informal education is nondeliberate education. Those with a propensity to postpone consumption save more and have fewer children (Friedman, Hechter, and Kanazawa 1994). This is not a competing argument; rather, it is a critical mechanism by which sibship size is related to wealth in adulthood. The strong positive relationship between educational attainment and wealth accumulation has been partially attributed to the preference for delayed consumption, and those who are upwardly mobile have a relatively strong preference to delay gratification (Dynan 1993). In turn, increased education directly increases wealth. In families that save, children learn to postpone consumption, and their accumulation of wealth in adulthood is thus greater. Parents who postpone consumption have more resources and fewer children and teach 
their children to postpone as well. This is not a spurious relation; rather, it is one reason why these children save more as adults.

\section{INTER VIVOS FINANCIAL TRANSFERS, INHERITANCE, AND WEALTH IN ADULTHOOD}

Figure 1 also suggests that sibship size affects wealth in adulthood by decreasing direct financial transfers from parents to children. There are two types of direct financial transfers: inter vivos transfers and inheritance, and siblings reduce both. Inter vivos transfers include direct financial transfers of money and other transfers, such as payments for college, purchases of automobiles early in life, and assistance in buying a home later in life. Parental resources can reduce the need for children to accumulate educational debt during college or graduate school. Other life transitions may also be easier for children whose parents have sufficient resources. If their resources are adequate, parents may help their adult children purchase a first home, establish a household after marriage, and prepare for and take care of children. Assistance with homeownership, in particular, can be an important inter vivos transfer. Homeownership is a core component of a stable wealth portfolio. In addition, because investing in a home is the most typical first investment for Americans, homeowners are more likely also to own stocks, mutual funds, and bonds (Keister 2000b). Because additional siblings reduce the likelihood of parental assistance with a down payment on a home, homeownership will be delayed. Investment in other financial assets, such as stocks, may also be delayed.

Sibship size also decreases inheritance when parents have resources to bequeath after their death (Blake 1989). As sibship size increases in families with resources available to make intergenerational transfers, each child is subsequently less likely to inherit because additional siblings reduce parental savings and thereby decrease the wealth that can be bequeathed. If there are sufficient resources remaining, children in larger families will inherit a smaller amount because inheritance in the United States is typically divided equally among offspring. A smaller or completely diminished inheritance changes the point at which a child begins to accumulate wealth. Any direct transfer of financial resources from parents to children has the potential to provide a base savings that can grow even if additional savings are never added. A reduced inheritance postpones the age at which wealth accumulation can begin, and because long-term compounding adds significantly to net worth, the long-term rate of accumulation may be significantly decreased when inheritance is lower.

Inter vivos transfers and inheritance increase wealth in adulthood by increasing the resources that adult children have to save, decreasing the need to assume debt, and improving the financial trajectory on which they begin to accumulate assets. Direct transfers of resources from parents to children may also alter the types of assets and debts a person owns as an adult and hence may change long-term patterns of wealth accumulation and mobility. Inherited wealth is often used to make a down payment on a home (McNamee and Miller 1998). Because even a relatively small inheritance can have a substantial effect on the likelihood of homeownership, inheritance can create a stable base for saving throughout the life course. A reduced inheritance is likely to reduce total wealth; lower the probability of homeownership; and lower the probability of investment in high-risk assets, such as stocks. The lower likelihood of homeownership and financial investment will further reduce wealth in adulthood.

\section{DATA}

My data came from the NLS-Y79. The NLS-Y, a nationally representative longitudinal survey that was administered 19 times between 1979 and 2000, includes detailed information about a large sample of young adults and is well-suited for assessing the effect of traits of the family of origin on later life outcomes (McLanahan and Sandefur 1994; 
Sandefur and Wells 1999; Wu 1996). The survey first interviewed 12,686 individuals who were born between 1957 and 1964 and who were aged 14-22 in 1979. The original sample included three subsamples: a nationally representative sample of 6,111 young adults; a supplemental sample of 5,295 poor white, black, and Hispanic respondents; and 1,280 young men and women in the military. Although cutbacks in funding forced the elimination of most of the poor and military oversamples, nearly 10,000 respondents were regularly interviewed through 2000. Missing values on wealth variables forced my sample size lower in the analyses I report here.

Detailed questions about wealth were added to the NLS-Y in 1985 when the respondents were aged 20-28. I used data from 1985 through 2000 (the respondents were aged 35-43 in 2000). I also drew on the 1979 survey and other years between 1979 and 1985 to create family-background and other measures. The NLS-Y wealth modules ask respondents first if they own a series of assets and debts. For those who are owners, the survey then asks for the current market value. Wealth questions were not asked in 1991, and starting in 1994, the NLS-Y was administered every other year, rather than every year. Thus, there are no data for 1991, 1995, and 1997 (Zagorsky 1997). The NLS-Y is one of the few data sets that contains detailed, longitudinal data on wealth for a large sample. Because the survey has been conducted frequently and has maintained high participation rates, it contains extensive information on the dynamics of wealth ownership (Zagorsky 1999).

The combination of its information on family processes in childhood and transitions to adulthood and its detailed data on wealth make the NLS-Y appropriate for exploring the relationship between family background and wealth in adulthood. Other sources of survey data on wealth ownership provide more comprehensive coverage of the families who own the bulk of wealth. The Survey of Consumer Finances (SCF), a series of panel surveys, oversamples high-income households to capture more accurately the distribution of wealth (Kennickell and Starr-McCluer 1994; Kennickell, Starr-McCluer, and Sunden 1997; Wolff 1995). Because the NLS-Y does not oversample high-income households, it slightly underestimates the value of wealth (Juster and Keuster 1991; Juster, Smith, and Stafford 1999). However, the underestimates are slight, and the cross-sectional estimates of the distribution of wealth are largely consistent with the SCF. Moreover, the oversample is less important here than it would be in analyses of the distribution of wealth. Studying the relationship between processes at different stages of the life course requires longitudinal coverage and information on holdings of wealth, both of which the NLS-Y offers.

\section{MEASURES}

I used four dependent variables in the analyses, one main and three supplementary outcomes. The primary outcome, net assets, allowed me to test the main arguments depicted in Figure 1. The supplementary measures were the probability of receiving a trust account, the probability of receiving an inheritance, the probability of owning a home, and the probability of owning stocks. I modeled these measures to explore components of the main theoretical model.

In the first analyses, I modeled the dollar value of adults' net assets (standardized and logged) and allowed this value to vary yearly between 1985 and $2000 .^{3}$ Net assets is the value of total assets less the value of total liabilities. The financial assets included the value of stocks, bonds, and mutual funds; cash accounts such as checking accounts; trust accounts; individual retirement accounts; $401 \mathrm{~K}$ plans; and certificates of deposit. The real assets included the current market value of the primary residence or home; businesses,

3. Net assets is skewed because wealth ownership is highly concentrated. Adding a constant to this variable (to eliminate negative values) and logging it reduces the skew. I explored the effect of removing outliers and found that given the large sample size, the results are robust to the removal of outliers. 
farms, and investment real estate; cars and other vehicles; and other possessions. The debts included mortgages on the primary residence; debts on businesses, farms, and investment real estate; debts on automobiles; and other debts. I used the CPI to adjust all asset and debt values to 2000 dollars.

In the additional analyses, I modeled four dichotomous variables. First, I modeled the likelihood that a respondent ever received a trust account from his or her parents. Second, I modeled the likelihood that a respondent ever received an inheritance, including an inheritance received both during the 1985-2000 period, when the NLS asked specific questions about wealth, and prior to 1985 . The dependent variable was a dichotomous indicator that a respondent ever received an inheritance. ${ }^{4}$ Third, I modeled the likelihood that a respondent owned a home, and fourth, I modeled the likelihood that a respondent owned stocks. I modeled the dichotomous indicator that a respondent owned a home or stocks because my argument is that education and financial transfers affect portfolio behavior (i.e., including the presence of particular assets or debts in the portfolio), rather than the amount. The results of models of the value of the home and stocks were not different from those I report.

I used the total number of siblings a respondent ever had, reported in 2000, to indicate family size in childhood. Decomposing total siblings (e.g., number of older and number of younger siblings) did not improve the model fit. Controlling for position among siblings and related measures (e.g., oldest, youngest, middle; spacing; and gender) did not increase the model power. I included stepsiblings and half-siblings who lived in the home. Excluding nonbiological siblings from the analysis and including only siblings who lived in the home for extended periods did not affect the results.

I introduced numerous individual- and family-level attributes to explore my arguments about the relationship between siblings and wealth in adulthood. I controlled for financial resources in the family of origin by including a measure of parents' net family income in 1978 (logged). I also included a dummy variable indicating that a respondent had not provided information about family income in 1978 to control for patterns that might be common to those with missing values on this key variable (Sandefur and Wells 1999). In addition, I included several measures of parents' education: separate dummy variables indicating whether a respondent's father and mother had completed high school, some college, a bachelor's degree, or an advanced degree. The omitted category for education was parents who had not completed high school. The detailed measures of educational attainment provide insight into the level of education that was relevant to children's wealth attainment in this cohort. Taken together, parents' income and education are an excellent proxy for their wealth, which is not available in this survey. When I also included measures of trusts and inheritances received (described later), I captured both the parents' ability to generate wealth and the actual wealth the parents acquired. Previous research has suggested that these measures account for most of the variance in parental wealth (Keister 2000b). Preliminary exploration using imputation, simulation, and synthetic measures of wealth for the parents produced identical substantive outcomes. I opted to include income and education to ease the interpretation. ${ }^{5}$

I argued earlier that siblings shape available resources per child and that these resources affect education and intergenerational financial transfers. To examine how the respondents' educational attainment affected their wealth, I included a series of dummy variables for education indicating whether a respondent had completed high school, some

4. Modeling the value of the inheritance received produced similar results.

5. Ideally, I would also have been able to control for parents' nonmaterial resources, such as the frequency with which the respondents spent time with their parents, whether the parents knew their children's friends, and the parents' educational aspirations for their children (Downey 1995). Unfortunately, data on parents' nonmaterial resources and time investment in their children are not available in the NLS, nor are there other data sets that contain measures of both parental time and wealth in adulthood. 
college, a bachelor's degree, or an advanced degree. The omitted category for education was respondents who had not completed high school.

To measure intergenerational transfers of resources, I included a dummy variable indicating whether a respondent ever inherited, and for those who inherited, I included a continuous variable indicating the amount inherited by year (standardized, logged, and converted to 2000 dollars using the CPI). ${ }^{6}$ Although it can be difficult to generate accurate estimates of inheritance, the NLS-Y estimates are consistent with measures of inherited wealth in other studies (McNamee and Miller 1998). I also included a dummy variable indicating whether a respondent received a trust account from his or her parents.

I included four measures to explore the role that financial behavior and saving trajectories play in this process. The first two variables capture the effect of financial behavior. The percentage of a respondent's portfolio accounted for by stocks and bonds (for owners) indicates the extent to which the person has invested in financial assets. Financial assets, particularly stocks and bonds, typically grow more rapidly than less-risky investments and usually lead to a higher overall growth of assets. In contrast, those who invest higher proportions of their assets in fixed investments, particularly housing, tend to accumulate wealth more slowly. Similarly, different accumulation trajectories yield different wealth outcomes. In the final model of net assets, I included indicators that a respondent made an early transition to financial wealth or followed a traditional accumulation path. I included respondents in the early-transition-to-financial-wealth group if they owned nonpension stocks or bonds before age 25 , owned at least $\$ 1,000$ in these assets in the earliest year, and continued to invest in stocks and bonds through the latest survey year. I included respondents in the traditional-accumulation group if they purchased a home during adulthood, did not own more than $\$ 1,000$ in stocks and bonds before they owned a house, and continued to own a home for at least five years. The omitted category was all other respondents. ${ }^{7}$

In addition to these test variables, I included a number of control variables in each model. I included two dummy variables to indicate whether a respondent was black or Hispanic, as opposed to white. I indicated age in number of years in the current year. ${ }^{8} \mathrm{I}$ included a dummy variable indicating whether a respondent was male. I also controlled for the religion in which a respondent was raised, using information from the 2000 survey. Specifically, I included dummy variables indicating that a respondent was raised Jewish, Roman Catholic, Episcopalian, or other Protestant (Keister forthcoming). The omitted category was all other religions. ${ }^{9}$

To control for the effect of family disruption on family resources and children's wellbeing (Mechanic and Hansell 1989), I included two indicators of a respondent's family structure at age 14. The variables indicate whether a respondent lived in a stepparent

6. Including those who did not inherit (i.e., those with a zero value) did not appreciably change the results. I used the amount ever inherited because it more closely matches the concept that, I argue, will affect wealth ownership.

7. I experimented with various methods of creating this indicator, including using the dollar value of stocks, housing investments, and other types of financial investments with stocks and bonds. The grouping of respondents varied little when I made these changes, and the findings did not change. In other analyses, I used optimal matching to identify accumulation paths. Optimal matching is a method designed to identify common patterns or trajectories and is based on the notion that one can measure how similar two sequences are by determining how difficult it is to transform one into the other. The measures I include here correlate at more than .90 with similar measures derived through optimal matching. I present the simplified measures here for ease of interpretation.

8. I did not control for the square of age because wealth accumulation does not typically follow the standard curvilinear relationship with age that income follows. A preliminary investigation confirmed that the squared age term was not a significant predictor of the ownership of assets in these data.

9. I included those who were not raised in a particular religion in the omitted category. Separating this group did not change the coefficients on the religion variables. 
family or a single-parent family, as opposed to a two-biological-parent family, at age 14 . Although I explored including various other indicators of the structure of a respondent's family of origin, this combination of variables captured the relationship between family structure and wealth outcomes most effectively.

I controlled for characteristics of a respondent's adult family situation. I included a dummy variable indicating whether a respondent was married (as opposed to all other marital statuses) in the current year. ${ }^{10} \mathrm{I}$ also included a dummy variable indicating whether a respondent was ever divorced to capture the cumulative effects of marital disruption. I included a dummy variable indicating whether a respondent ever had a biological child and a continuous variable indicating the number of children born to a respondent (for those who had children). Finally, I included a variable that was an interaction between ever having been divorced and ever having children to indicate the magnification of the negative effects of divorce involving children.

To capture the level of nonwealth financial resources available in a respondent's household, I controlled for a respondent's income (logged) in the current year and a respondent's spouse's income (logged) in the current year. I included a variable indicating the amount of income from entrepreneurial activities to capture the effect of entrepreneurship on wealth accumulation. I also included a continuous variable indicating the number of weeks $a$ respondent's spouse worked in the previous year. In including indicators of a respondent's spouse's contribution to the household economy, I hoped to capture the effects of added financial resources that came into the household either through the spouse's work or independent wealth. Table 1 presents the means and standard deviations for the familybackground and individual variables. These estimates are consistent with other estimates of family size, attainment, and ownership of wealth. All the tables report the actual number of respondents, rather than the total person-years, included in the analysis.

\section{METHODS}

I used pooled cross-section time-series analyses to model wealth ownership. Thus, the unit of analysis in all models was the person-year between 1985 and 2000, and both independent and dependent variables could change in each year. I used estimated generalized least-squares (EGLS) regression to model net assets because the error terms were both heteroskedastic and correlated over time. ${ }^{11}$ I used logistic regression to model the likelihood that the respondent received a trust or an inheritance, owned a home, or owned stock.

To understand how sibship size affects overall wealth, I estimated a series of nested models of net assets. I first regressed net assets on total siblings and the control variables. In subsequent models, I entered parents' financial resources, respondents' education and direct financial transfers, and measures of financial (portfolio) behavior and saving trajectory. I entered the additional variables in this order to explore the degree to which the additional measures reduced the effect of sibship size on wealth in adulthood and to represent the causal arguments I proposed earlier. To explore the mechanisms underlying the relationship between siblings and net assets further, I repeated the full model for the

10. I experimented with more-detailed marital-status controls, including for those who were never married, divorced and the timing of divorce, widowed and the timing of widowhood, and various combinations of changes in marital status. However, my findings were robust; the more-detailed marital-status controls did not improve the model fit, and I had no theoretical reason to control for marital status and status changes other than those I included in the models reported here.

11. The White's test for heteroskedasticy was significant, and the ordinary Durbin-Watson test (D-W) for first-order autocorrelation was significantly different from 2. Because the ordinary D-W was significant, it was not necessary to use the general D-W for higher orders of autocorrelation. Practically, I used the Yule-Walker method, also known as the two-step full transform method, or EGLS, in SAS Proc Autoreg to estimate the models (Judge et al. 1985). 
Table 1. Descriptive Statistics for Variables Included in the Analyses, NLS-Y, 1979-2000

\begin{tabular}{|c|c|c|c|c|c|}
\hline Variable & Mean & $S D$ & Variable & Mean & $S D$ \\
\hline Adults' Wealth Ownership & & & Other Test Variables & & \\
\hline Net assets, $1985^{\mathrm{a}}(\$)$ & & & Number of siblings & 2.92 & 2.25 \\
\hline Mean & 24.7 & & Parents' income ${ }^{c}(\$)$ & 38.14 & 40.07 \\
\hline Median & 5.1 & 62.0 & Father's education $^{\mathrm{d}}$ & & \\
\hline Net assets, $2000(\$)$ & & & High school & .33 & .47 \\
\hline Mean & 148.3 & & Some college & .10 & .30 \\
\hline Median & 48.11 & 452.1 & College degree & .10 & .30 \\
\hline Ever inherited & .42 & .49 & Advanced degree & .07 & .25 \\
\hline Amount inherited ${ }^{\mathrm{a}, \mathrm{b}}(\$)$ & 1,882 & 21,872 & Mother's education $^{\mathrm{d}}$ & & \\
\hline Received a trust & .04 & .21 & High school & .44 & .50 \\
\hline Owned a home, 2000 & .67 & .47 & Some college & .09 & .33 \\
\hline Owned stocks or bonds, 2000 & .26 & .44 & College degree & .05 & .35 \\
\hline Percentage of portfolio & & & Advanced degree & .02 & .15 \\
\hline accounted for by & & & Respondent's education $^{\mathrm{d}}$ & & \\
\hline Stocks and bonds, 2000 & .02 & .08 & High school & .37 & .48 \\
\hline Primary residence, 2000 & .30 & .37 & Some college & .18 & .39 \\
\hline Traditional accumulation path & .18 & .22 & College degree & .12 & .31 \\
\hline $\begin{array}{l}\text { Early transition to } \\
\text { financial wealth }\end{array}$ & .02 & .03 & Advanced degree & .08 & .28 \\
\hline Select Control Variables & & & Select Control Variables (cont. & & \\
\hline Black & .12 & .32 & Family structure at age 14 & & \\
\hline Hispanic & .07 & .26 & Stepparent family & .08 & .28 \\
\hline Male & .49 & .50 & Single-parent family & .13 & .33 \\
\hline Family religion (childhood) & & & Adult family & & \\
\hline Jewish & .02 & .10 & Married & .48 & .51 \\
\hline Catholic & .26 & .44 & Ever divorced & .22 & .41 \\
\hline Episcopalian & .01 & .12 & Ever had children & .82 & .38 \\
\hline \multirow[t]{2}{*}{ Protestant } & .54 & .30 & Number of children & 1.15 & 1.25 \\
\hline & & & Family income, $2000(\$)$ & 65.8 & 40.5 \\
\hline
\end{tabular}

${ }^{\mathrm{a} C}$ Converted to 2000 dollars using the CPI.

${ }^{\mathrm{b}}$ Average yearly inheritance between 1988 and 2000; includes only those who ever inherited.

${ }^{c}$ Income in 1978 dollars. Converted to 2000 dollars using the CPI; mean $=\$ 38,144(S D=\$ 40,065)$.

${ }^{\mathrm{d}}$ Education is the highest level completed.

dichotomous dependent variables, omitting certain variables (e.g., inheritance measures in the models of inheritance).

\section{RESULTS}

\section{Siblings Reduce Wealth by Reducing Resources and Education}

Siblings shape adults' wealth accumulation in a number of ways. Perhaps the most apparent and direct effect is through education. To examine the relationship between sibship size and wealth in adulthood, I conducted a series of multivariate analyses. I first explored 
the relationship between sibship size and adults' wealth by regressing overall wealth in adulthood, measured as net assets, on the number of siblings. In these models, I controlled for various individual and family traits, including race, age, gender, religion, family structure during childhood, marital status, divorce history, children, adult family resources, immigrant status, and region of residence. Table 2 reports the results of a series of regression equations using alternative model specifications of this basic model in which the alternatives were included to demonstrate the robustness of the central finding about siblings and to provide some insight into the reason for this finding. Model 1 includes the total number of siblings and the controls to document the basic relationship between siblings and wealth in adulthood. Consistent with the notion that having more siblings decreases well-being later in life, there is a strong negative relationship between sibship size and adults' net worth. The basic model is also consistent in other respects with the literature on the ownership of wealth. Blacks and Hispanics have considerably less wealth than do whites. There are also strong positive relationships among being raised Jewish, being married, and having entrepreneurial income and wealth ownership.

Siblings affect wealth, at least in part, by reducing the resources available to each child in the family of origin. Model 2 introduces a number of measures of parents' resources, including their income and education. Both income and parents' education increase wealth in adulthood and decrease the effect of siblings on such wealth. Income in the childhood family is a strong positive predictor of wealth in adulthood. Similarly, parents' education is generally associated with higher levels of wealth in adulthood. In particular, all levels of education for fathers increased the adult children's wealth, whereas mothers with college degrees were the most likely to have children who accumulated assets. At least in part because mothers with advanced degrees were rare in the generations represented here, the effect of mothers with an education beyond a college degree was not significantly different from zero. Cox tests confirmed that the family-resources and parental-education variables also significantly reduced the direct effect of siblings on wealth in adulthood. I argued that sibship size reduces the resources available to each child, and the finding that childhood family resources reduce the effect of sibship supports this argument. Parents' resources, evident in parents' income and education, improve educational opportunities for children; provide access to educational materials, such as newspapers; and allow parents to teach their children about saving and investing. In larger families, these benefits are more limited.

If family resources reduce educational attainment, a respondent's own education should reduce the effects of test variables introduced in Models 1 and 2 of Table 2. Model 3 in the same table investigates this hypothesis. Specifically, in Model 3, I introduced the measures of respondents' education and found support for my argument. Education has a strong, positive relationship with wealth in adulthood and decreases the effect of siblings and parents' resources. Again, a respondent's education increases wealth in adulthood, and Cox tests confirmed that the addition of measures of a respondent's education reduces the effect of sibship size on such wealth. Consistent with my theoretical arguments, however, the effect of siblings remains relatively strong in Model 3.

\section{Siblings Reduce Wealth in Adulthood by Reducing Direct Financial Transfers}

In addition to affecting educational attainment, siblings reduce direct financial transfers from parents to children, which is likely, in turn, to reduce wealth in adulthood. In Model 4 of Table 2, I introduced three measures to test this hypothesis. The dichotomous indicator that a respondent ever inherited is positive and has a strong, significant association with wealth in adulthood. Similarly, for those who inherited, the amount inherited increases wealth. Finally, there is a strong, positive relationship between receiving a trust account and ownership of wealth in adulthood. These measures also reduce the effect of 
Table 2. EGLS Parameter Estimates for the Effect of Siblings on Adult Net Assets, 1985-2000 $(n=5,687)$

\begin{tabular}{|c|c|c|c|c|c|}
\hline Variable & Model 1 & Model 2 & Model 3 & Model 4 & Model 5 \\
\hline Number of Siblings & $\begin{array}{l}-4.06^{* * *} \\
(0.77)\end{array}$ & $\begin{array}{l}-2.71^{* * *} \\
(0.79)\end{array}$ & $\begin{array}{l}-2.62^{* * *} \\
(0.79)\end{array}$ & $\begin{array}{l}-1.53^{* *} \\
(0.60)\end{array}$ & $\begin{array}{c}-1.08^{*} \\
(0.53)\end{array}$ \\
\hline \multicolumn{6}{|l|}{ Parents' Financial Resources } \\
\hline Family income (log) & - & $\begin{array}{l}1.09^{*} \\
(0.47)\end{array}$ & $\begin{array}{l}0.85^{*} \\
(0.45)\end{array}$ & $\begin{array}{c}0.98 \\
(0.77)\end{array}$ & $\begin{array}{c}0.88 \\
(0.77)\end{array}$ \\
\hline Family income not reported & - & $\begin{array}{c}7.44 \\
(5.79)\end{array}$ & $\begin{array}{c}5.17 \\
(5.79)\end{array}$ & $\begin{array}{l}3.09 \\
(9.48)\end{array}$ & $\begin{array}{l}2.16 \\
(9.49)\end{array}$ \\
\hline \multicolumn{6}{|l|}{ Father's Education } \\
\hline High school & - & $\begin{array}{l}13.72^{* * *} \\
(4.09)\end{array}$ & $\begin{array}{l}11.64^{* * *} \\
(4.10)\end{array}$ & $\begin{array}{l}14.71 \\
(6.70)\end{array}$ & $\begin{array}{l}16.48 \\
(6.69)\end{array}$ \\
\hline Some college & - & $\begin{array}{l}15.73^{* *} \\
(6.02)\end{array}$ & $\begin{array}{c}10.93^{*} \\
(6.06)\end{array}$ & $\begin{array}{l}14.34 \\
(9.91)\end{array}$ & $\begin{array}{l}11.43 \\
(9.93)\end{array}$ \\
\hline College degree & - & $\begin{array}{l}25.17^{* * *} \\
(6.43)\end{array}$ & $\begin{array}{l}16.24^{* *} \\
(6.56)\end{array}$ & $\begin{array}{c}15.48 \\
(10.70)\end{array}$ & $\begin{array}{c}6.90 \\
(10.70)\end{array}$ \\
\hline Advanced degree & - & $\begin{array}{l}40.73^{* * *} \\
(7.59)\end{array}$ & $\begin{array}{l}30.74^{* * *} \\
(7.71)\end{array}$ & $\begin{array}{c}29.23^{* *} \\
(12.63)\end{array}$ & $\begin{array}{c}24.93^{*} \\
(12.65)\end{array}$ \\
\hline \multicolumn{6}{|l|}{ Mother's Education } \\
\hline High school & - & $\begin{array}{c}5.50 \\
(4.06)\end{array}$ & $\begin{array}{c}2.27 \\
(4.09)\end{array}$ & $\begin{array}{l}3.06 \\
(6.68)\end{array}$ & $\begin{array}{l}1.48 \\
(6.67)\end{array}$ \\
\hline Some college & - & $\begin{array}{l}16.12^{* *} \\
(6.32)\end{array}$ & $\begin{array}{c}10.11^{*} \\
(6.39)\end{array}$ & $\begin{array}{c}8.35 \\
(10.42)\end{array}$ & $\begin{array}{c}9.34 \\
(10.41)\end{array}$ \\
\hline College degree & - & $\begin{array}{l}39.82^{* * *} \\
(7.55)\end{array}$ & $\begin{array}{l}30.57^{* * *} \\
(7.66)\end{array}$ & $\begin{array}{c}30.25^{*} \\
(12.52)\end{array}$ & $\begin{array}{c}15.76 \\
(12.51)\end{array}$ \\
\hline Advanced degree & - & $\begin{array}{c}10.18 \\
(11.39)\end{array}$ & $\begin{array}{c}0.22 \\
(11.47)\end{array}$ & $\begin{array}{c}-23.73 \\
(18.82)\end{array}$ & $\begin{array}{c}-15.71 \\
(19.05)\end{array}$ \\
\hline \multicolumn{6}{|l|}{ Respondent's Education } \\
\hline High school & - & - & $\begin{array}{c}6.92 \\
(4.90)\end{array}$ & $\begin{array}{l}5.69 \\
(8.11)\end{array}$ & $\begin{array}{l}10.31 \\
(8.09)\end{array}$ \\
\hline Some college & - & - & $\begin{array}{l}16.64^{* *} \\
(5.64)\end{array}$ & $\begin{array}{l}15.19^{*} \\
(9.33)\end{array}$ & $\begin{array}{l}15.92 \\
(9.32)\end{array}$ \\
\hline College degree & - & - & $\begin{array}{l}36.90^{* * *} \\
(6.52)\end{array}$ & $\begin{array}{l}41.91^{* * *} \\
(10.79)\end{array}$ & $\begin{array}{c}28.87^{*} \\
(10.79)\end{array}$ \\
\hline Advanced degree & - & - & $\begin{array}{l}42.04^{* * *} \\
(7.29)\end{array}$ & $\begin{array}{l}55.03^{* * *} \\
(12.06)\end{array}$ & $\begin{array}{l}37.77^{* *} \\
(12.07)\end{array}$ \\
\hline \multicolumn{6}{|l|}{ Intergenerational Financial Transfers } \\
\hline Ever inherited & - & - & - & $\begin{array}{l}13.41^{* *} \\
(5.62)\end{array}$ & $\begin{array}{l}9.02^{*} \\
(5.62)\end{array}$ \\
\hline Amount inherited & - & - & - & $\begin{array}{c}0.01^{* * *} \\
(0.001)\end{array}$ & $\begin{array}{c}0.01^{\text {*** }} \\
(0.001)\end{array}$ \\
\hline Received a trust fund & - & - & - & $\begin{array}{l}351.89^{* * *} \\
(12.64)\end{array}$ & $\begin{array}{l}352.07^{* * *} \\
(12.79)\end{array}$ \\
\hline \multicolumn{6}{|l|}{ Financial Behavior and Trajectory } \\
\hline Percentage of stocks and bonds & - & - & - & - & $\begin{array}{l}414.94^{* * *} \\
(39.43)\end{array}$ \\
\hline Percentage of housing assets & 一 & - & - & - & $\begin{array}{c}-38.46^{* * *} \\
(8.05)\end{array}$ \\
\hline $\begin{array}{l}\text { Early transition to } \\
\text { financial wealth }\end{array}$ & - & - & - & - & $\begin{array}{l}119.42^{* * *} \\
(71.57)\end{array}$ \\
\hline
\end{tabular}


(Table 2, continued)

\begin{tabular}{|c|c|c|c|c|c|}
\hline Variable & Model 1 & Model 2 & Model 3 & Model 4 & Model 5 \\
\hline \multicolumn{6}{|l|}{$\begin{array}{l}\text { Financial Behavior and } \\
\text { Trajectory (cont.) }\end{array}$} \\
\hline Traditional accumulation path & - & - & - & - & $\begin{array}{l}-130.06^{* * *} \\
(13.33)\end{array}$ \\
\hline \multicolumn{6}{|l|}{ Controls } \\
\hline Black & $\begin{array}{l}-29.45^{* * *} \\
(5.58)\end{array}$ & $\begin{array}{l}-25.69^{* * *} \\
\quad(5.61)\end{array}$ & $\begin{array}{l}-26.00^{* * *} \\
(5.62)\end{array}$ & $\begin{array}{l}-21.65^{* * *} \\
(9.25)\end{array}$ & $\begin{array}{l}-19.54^{* * *} \\
\quad(9.27)\end{array}$ \\
\hline Hispanic & $\begin{array}{c}-36.15^{* * *} \\
(7.35)\end{array}$ & $\begin{array}{l}-28.02^{* * *} \\
(7.48)\end{array}$ & $\begin{array}{l}-27.22^{* * *} \\
(7.49)\end{array}$ & $\begin{array}{l}-30.90^{* * *} \\
(12.28)\end{array}$ & $\begin{array}{l}-25.00^{* * *} \\
(12.24)\end{array}$ \\
\hline Age & $\begin{array}{l}7.99^{* * *} \\
(0.35)\end{array}$ & $\begin{array}{l}7.95^{* * *} \\
(0.35)\end{array}$ & $\begin{array}{l}7.78^{* * *} \\
(0.35)\end{array}$ & $\begin{array}{l}7.35^{* * *} \\
(0.60)\end{array}$ & $\begin{array}{l}7.23^{* * *} \\
(0.61)\end{array}$ \\
\hline Male & $\begin{array}{l}8.70^{* *} \\
(3.25)\end{array}$ & $\begin{array}{l}7.09^{*} \\
(3.27)\end{array}$ & $\begin{array}{l}8.54^{*} \\
(3.29)\end{array}$ & $\begin{array}{l}12.17^{*} \\
(5.36)\end{array}$ & $\begin{array}{l}6.39^{*} \\
(5.36)\end{array}$ \\
\hline \multicolumn{6}{|l|}{ Family Religion } \\
\hline Jewish & $\begin{array}{l}145.74^{* * *} \\
(16.14)\end{array}$ & $\begin{array}{l}120.84^{* * *} \\
(16.34)\end{array}$ & $\begin{array}{l}118.18^{* * *} \\
(16.34)\end{array}$ & $\begin{array}{l}117.83^{* * *} \\
(26.34)\end{array}$ & $\begin{array}{l}82.43^{* *} \\
(26.41)\end{array}$ \\
\hline Catholic & $\begin{array}{l}12.01^{* *} \\
(4.00)\end{array}$ & $\begin{array}{l}9.45^{*} \\
(4.03)\end{array}$ & $\begin{array}{r}8.56^{*} \\
(4.05)\end{array}$ & $\begin{array}{c}8.54^{*} \\
(6.60)\end{array}$ & $\begin{array}{c}7.81 \\
(6.59)\end{array}$ \\
\hline Episcopalian & $\begin{array}{l}61.48^{* * *} \\
(12.71)\end{array}$ & $\begin{array}{l}45.55^{* * *} \\
(12.81)\end{array}$ & $\begin{array}{c}39.88^{* *} \\
(12.84)\end{array}$ & $\begin{array}{c}18.70 \\
(20.77)\end{array}$ & $\begin{array}{c}-1.36 \\
(20.90)\end{array}$ \\
\hline Protestant & $\begin{array}{c}-0.46 \\
(5.33)\end{array}$ & $\begin{array}{c}-2.85 \\
(5.34)\end{array}$ & $\begin{array}{c}-4.08 \\
(5.35)\end{array}$ & $\begin{array}{r}-11.35 \\
(8.67)\end{array}$ & $\begin{array}{c}-9.78 \\
(8.67)\end{array}$ \\
\hline \multicolumn{6}{|l|}{ Family Structure at Age 14} \\
\hline Stepparent family & $\begin{array}{r}-12.53^{*} \\
(5.79)\end{array}$ & $\begin{array}{l}-7.45 \\
(5.81)\end{array}$ & $\begin{array}{c}-5.74 \\
(5.81)\end{array}$ & $\begin{array}{r}-10.87 \\
(9.49)\end{array}$ & $\begin{array}{c}-8.53 \\
(9.48)\end{array}$ \\
\hline Single-parent family & $\begin{array}{c}-4.72 \\
(5.04)\end{array}$ & $\begin{array}{c}-0.60 \\
(5.08)\end{array}$ & $\begin{array}{c}-0.73 \\
(5.09)\end{array}$ & $\begin{array}{r}-10.61 \\
(8.33)\end{array}$ & $\begin{array}{r}-10.03 \\
(8.30)\end{array}$ \\
\hline \multicolumn{6}{|l|}{ Adult Family } \\
\hline Married & $\begin{array}{l}32.50^{* * *} \\
(3.66)\end{array}$ & $\begin{array}{l}30.85^{* * *} \\
(3.66)\end{array}$ & $\begin{array}{l}30.28^{* * *} \\
(3.67)\end{array}$ & $\begin{array}{l}30.74^{* * *} \\
(6.07)\end{array}$ & $\begin{array}{c}28.03^{* * *} \\
(6.36)\end{array}$ \\
\hline Ever divorced & $\begin{array}{c}14.30^{*} \\
(8.75)\end{array}$ & $\begin{array}{c}13.67^{*} \\
(8.75)\end{array}$ & $\begin{array}{c}13.58^{*} \\
(8.88)\end{array}$ & $\begin{array}{c}13.57^{*} \\
(8.07)\end{array}$ & $\begin{array}{c}13.19^{*} \\
(8.01)\end{array}$ \\
\hline Ever had children & $\begin{array}{c}-0.63 \\
(4.73)\end{array}$ & $\begin{array}{c}-0.97 \\
(4.73)\end{array}$ & $\begin{array}{c}1.02 \\
(4.74)\end{array}$ & $\begin{array}{l}10.54 \\
(7.91)\end{array}$ & $\begin{array}{c}14.48 \\
(7.88)\end{array}$ \\
\hline Number of children & $\begin{array}{c}0.90 \\
(1.81)\end{array}$ & $\begin{array}{c}3.31 \\
(1.83)\end{array}$ & $\begin{array}{c}4.84 \\
(1.85)\end{array}$ & $\begin{array}{c}5.18 \\
(2.91)\end{array}$ & $\begin{array}{c}4.62 \\
(2.91)\end{array}$ \\
\hline Divorced $\times$ had children & $\begin{array}{c}-14.80^{* * *} \\
(3.10)\end{array}$ & $\begin{array}{c}-14.15^{* * *} \\
(3.10)\end{array}$ & $\begin{array}{c}-13.91^{* * *} \\
(3.11)\end{array}$ & $\begin{array}{c}-13.60^{* *} \\
(5.04)\end{array}$ & $\begin{array}{c}-9.35^{* *} \\
(5.01)\end{array}$ \\
\hline \multicolumn{6}{|l|}{ Adult Resources } \\
\hline Family income & $\begin{array}{c}0.01^{* * *} \\
(0.001)\end{array}$ & $\begin{array}{l}0.01^{* * *} \\
(0.001)\end{array}$ & $\begin{array}{l}0.01^{* * *} \\
(0.001)\end{array}$ & $\begin{array}{l}0.01^{* * *} \\
(0.001)\end{array}$ & $\begin{array}{c}0.01^{* * *} \\
(0.001)\end{array}$ \\
\hline Entrepreneurial income & $\begin{array}{l}68.55^{* * *} \\
(7.53)\end{array}$ & $\begin{array}{l}67.24^{* * *} \\
(7.53)\end{array}$ & $\begin{array}{l}67.07^{* * *} \\
(7.53)\end{array}$ & $\begin{array}{l}55.70^{* * *} \\
(12.10)\end{array}$ & $\begin{array}{l}55.38^{* * *} \\
(12.07)\end{array}$ \\
\hline Adjusted $R^{2}$ & .15 & .16 & .18 & .20 & .28 \\
\hline
\end{tabular}

Notes: Standard errors are in parentheses. Sample size refers to the total number of respondents included, rather than the number of person-years. Also controlled, but not displayed, were indicators of whether the respondent was born outside the United States, whether either parent was born outside the United States, the number of weeks worked by the spouse, urban residence, and region of residence.

$$
{ }^{*} p<.05 ;{ }^{* *} p<.01 ;{ }^{* * *} p<.001
$$


siblings on wealth, suggesting that the mechanism I proposed has some merit. What is perhaps the most interesting finding is that the effect of siblings remained even when direct intergenerational transfers were controlled in Model 3. This finding implies that direct transfers are important predictors of wealth in adulthood, but that other forces are also important.

I argued that some of this remaining effect of siblings is a result of financial behavior and the trajectory along which people accumulate wealth. Understanding of financial decision making comes from formal channels, such as formal education, and informal channels, including parents' behavior and the lessons that parents teach. Those with more education tend to make financial decisions that yield higher wealth; likewise, those who learn about financial behavior from their parents are likely to make better financial decisions, to save earlier, and to accumulate wealth faster. Moreover, those who receive direct financial transfers of resources from their parents-both inter vivos transfers and inheritance-are likely to make financial decisions and to save in ways that will increase their wealth. In Model 5 of Table 2, I introduced four indicators to explore these ideas. Having a higher percentage of one's portfolio invested in stocks and bonds yields more wealth, and having a higher percentage of one's portfolio invested in housing decreases wealth. Similarly, those who made an early transition to financial wealth (invested in stocks and bonds early and before other assets) increased the value of their wealth notably, whereas those who followed a more traditional path in their savings accumulated markedly less than did other investors. Consistent with the arguments illustrated in Figure 1, the measures of financial behavior and trajectory reduce the effect of education and direct financial transfers, suggesting that education and transfers operate through these financial behaviors to shape wealth in adulthood.

Although the effect of siblings is lower in the final model in Table 2, sibship size is still strongly negatively associated with wealth in adulthood. This finding suggests that there are important factors that are not included in the models. Among these factors, social contacts are likely an important omission. Social contacts, such as friends from college, can provide capital for entrepreneurial ventures, can be an important source of information about investments, and can give referrals to those who can provide these important things. Another omitted group of measures are indicators of the nonmaterial resources that siblings dilute. I argued that the time parents have to assist their children with homework, to create educational opportunities, to encourage their children, and to intervene with problems are all reduced in larger families. I also argued that this reduced time is likely to affect the wealth of adult children by reducing children's educational attainment. Practically, it is not possible to test this argument because data on the time parents spent with children and adults' wealth ownership are not available. Ideally the NLS-Y would contain data on parents' nonmaterial resources, such as the frequency with which the respondents spent time with their parents, whether the parents knew their children's friends, and the parents' educational aspirations for their children, but it does not until much later cohorts. Although I do not demonstrate a causal relationship between nonmaterial resources and wealth in adulthood, the relationship between the dilution of family resources, both material and nonmaterial, and educational attainment has been well-documented elsewhere (Downey 1995). ${ }^{12}$

It is also possible that some of the remaining effect of siblings in Model 5, Table 2, reflects family differences in the propensity to postpone consumption. People who have a relatively high propensity to postpone consumption tend to accumulate greater wealth because they are more likely to save. Children learn saving behavior from their parents,

12. Moreover, it is not necessary to test all elements of a theoretical argument empirically to provide useful support for the arguments (see, for example, Cohen 1989; Popper 1965). The empirical evidence I provide lends support for but does not falsify my arguments regarding parents' nonmaterial resources. 
and to the extent that parents convey a message of postponed gratification, either in their own saving behavior or in other behaviors, children are likely to learn to save. In families in which postponed consumption, including postponing childbirth, is not the norm, children are less likely to learn to defer consumption and less likely to learn to save. The result is not a spurious relationship between sibship size and wealth in adulthood; rather, it reflects a family's propensity to save and to socialize children to behave similarly.

These analyses may be limited in other ways by spurious relations, a problem that is common in survey research and that has been debated in the literature on siblings (Downey et al. 1999; Guo and VanWey 1999). Specifically, because I was unable to control all factors that affect wealth accumulation, I cannot completely dismiss the potential for a spurious relationship. Although I was able to control for a large number of individual, family, and regional effects on wealth accumulation, there are naturally some factors that I was not able to measure directly. For example, it is possible that parents who plan carefully and save for their children's futures also have fewer children. These parents may transfer resources to their adult children while they are alive-inter vivos transfers - that the adult children do not report as an inheritance but that improve their ability to save and invest in adulthood. Such transfers may affect wealth but were not controlled in my models. Controlling for the receipt and size of inherited wealth is the single strongest control for this potentially spurious relationship. Moreover, even with inheritance controlled, the relationship between family size and wealth outcomes is relatively strong and consistent across the measures of wealth.

In each of these models, a respondent's educational attainment is a critical intervening process. To demonstrate the important relationship among siblings, education, and wealth in adulthood, I used the final model included in Table 2 to predict wealth ownership. Figure 2 depicts the predicted value of wealth at various educational levels and by the number of siblings. This figure uses Model 5 in Table 2 to predict wealth in adulthood; that is, all variables included in the final model in Table 2 are controlled in these estimated values. I included all those with 7 or more siblings in the final group even though the maximum number of siblings was 12 because only a small percentage of the respondents had more than 7 brothers and sisters. The figure highlights the steep decline in wealth at all educational levels as siblings are added to the family. Of course, those with greater education accumulate more wealth, regardless of how many siblings they have, but even those with advanced degrees accumulate considerably less overall wealth if they are from larger, rather than smaller, families. There appears to be a sharp increase in the effect for families with four or more children; extensive checking revealed that this effect was not the result of outliers.

\section{Siblings Reduce Transfers and Shape Saving Behavior}

To explore the mechanisms underlying these findings, I included an additional set of analyses in which financial transfers and financial behavior were the outcome variables. In Table 3, I model the effect of siblings and a series of other endogenous variables on the likelihood of receiving an inheritance, receiving a trust fund, owning a home, and owning stocks. One of my core arguments is that additional siblings reduce the resources that parents transfer directly to their children in the form of inter vivos transfers such as trusts and inheritances, and this reduction in resources, in turn, adversely affects adults' wealth accumulation. The results reported in Table 3 provide strong support for the first part of my argument. At all levels of family income and parental education, additional siblings reduce the likelihood of receiving a trust or inheriting. I also explored the size of the trust and the amount of inheritance received by regressing the value of the inheritance on the same independent variables. These analyses (not reported) also provided support for the argument that siblings have a direct, negative impact on inheritance. In both models, parents' financial resources and mother's education are directly related to 
Figure 2. Predicted Net Worth, by Number of Siblings and Education

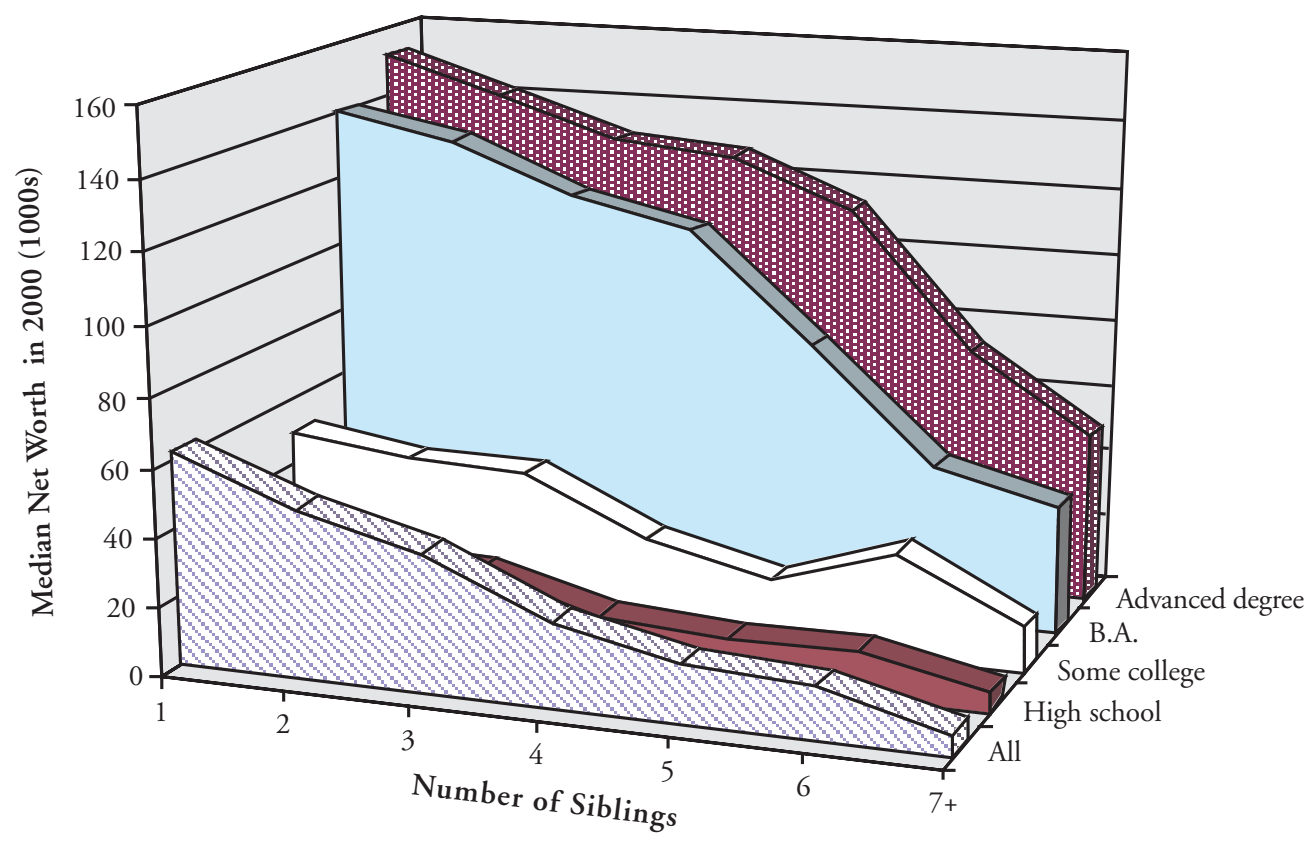

receiving a financial transfer. Father's income is positively related to receiving an inheritance, but except for children with fathers with advanced degrees, father's education is a weak predictor of receiving a trust. In these models, I did not control for a respondent's education because I argue that intergenerational transfers logically occur prior to educational attainment; that is, children whose parents have resources will complete additional schooling (as opposed to education affecting transfers). I also did not control for siblings' demographics (e.g., income, wealth) because the data are not available in the NLS-Y. Models of other assets (e.g., business, pensions) revealed similar patterns. In other research, I have explored the degree to which ownership of various assets is interrelated and how family background shapes these patterns (Keister forthcoming).

Siblings also reduce wealth in adulthood in more indirect ways, including through their effect on investment behavior. In particular, sibship size is negatively related to adults' ownership of two critical assets: a home and stocks. The family home is the cornerstone of most Americans' portfolios and has traditionally been the most common asset owned by households in the United States largely because it combines use value with an investment (Kennickell 2000). Homeownership has also historically been a relatively lucrative investment and has, therefore, been an important component of the portfolios of those who are financially secure (Keister 2000b). In recent years, stock ownership has become more accessible to more Americans as mutual funds have become more common, on-line investing has grown in popularity, and new financial instruments that invest in stocks have become accessible to more people (Norris 1996). At the same time, stock market booms during the 1990s have made investing in stocks a central component of a growing investment portfolio. Of course, the likelihood of owning either of 
Table 3. Logistic Regression Parameter Estimates for the Effect of Siblings on Wealth, $1985-2000(n=5,687)$

\begin{tabular}{|c|c|c|c|c|}
\hline Variable & $\begin{array}{l}\text { Received a } \\
\text { Trust Account }\end{array}$ & $\begin{array}{c}\text { Ever } \\
\text { Inherited }\end{array}$ & $\begin{array}{c}\text { Own } \\
\text { a Home }\end{array}$ & $\begin{array}{l}\text { Own } \\
\text { Stocks }\end{array}$ \\
\hline Number of Siblings & $\begin{array}{l}-0.07^{* * *} \\
(0.01)\end{array}$ & $\begin{array}{c}-0.04^{* * *} \\
(0.01)\end{array}$ & $\begin{array}{c}-0.08^{* *} \\
(0.01)\end{array}$ & $\begin{array}{c}-0.05^{* *} \\
(0.01)\end{array}$ \\
\hline \multicolumn{5}{|l|}{ Parents' Financial Resources } \\
\hline Family income (log) & $\begin{array}{l}0.02^{* *} \\
(0.01)\end{array}$ & $\begin{array}{l}0.02^{* * *} \\
(0.00)\end{array}$ & $\begin{array}{c}0.01 \\
(0.01)\end{array}$ & $\begin{array}{c}0.01 \\
(0.00)\end{array}$ \\
\hline Family income not reported & $\begin{array}{c}-0.06 \\
(0.09)\end{array}$ & $\begin{array}{l}0.23^{* * *} \\
(0.03)\end{array}$ & $\begin{array}{c}0.03 \\
(0.05)\end{array}$ & $\begin{array}{c}0.02 \\
(0.06)\end{array}$ \\
\hline \multicolumn{5}{|l|}{ Father's Education } \\
\hline High school & $\begin{array}{c}0.12 \\
(0.07)\end{array}$ & $\begin{array}{l}0.25^{\text {*** }} \\
(0.02)\end{array}$ & $\begin{array}{c}0.06 \\
(0.04)\end{array}$ & $\begin{array}{l}0.09^{*} \\
(0.04)\end{array}$ \\
\hline Some college & $\begin{array}{c}0.11 \\
(0.09)\end{array}$ & $\begin{array}{l}0.23^{* * *} \\
(0.03)\end{array}$ & $\begin{array}{c}-0.14 \\
(0.05)\end{array}$ & $\begin{array}{l}0.25^{\text {*** }} \\
(0.05)\end{array}$ \\
\hline College degree & $\begin{array}{c}0.16 \\
(0.09)\end{array}$ & $\begin{array}{l}0.61^{\text {*** }} \\
(0.04)\end{array}$ & $\begin{array}{c}0.06 \\
(0.06)\end{array}$ & $\begin{array}{l}0.38^{* * *} \\
(0.06)\end{array}$ \\
\hline Advanced degree & $\begin{array}{l}0.37^{* * *} \\
(0.10)\end{array}$ & $\begin{array}{l}1.04^{* * *} \\
(0.05)\end{array}$ & $\begin{array}{c}-0.12 \\
(0.07)\end{array}$ & $\begin{array}{l}0.33^{* * *} \\
(0.06)\end{array}$ \\
\hline \multicolumn{5}{|l|}{ Mother's Education } \\
\hline High school & $\begin{array}{l}0.12^{* * *} \\
(0.07)\end{array}$ & $\begin{array}{l}0.21^{\text {*** }} \\
(0.02)\end{array}$ & $\begin{array}{l}0.10^{* *} \\
(0.04)\end{array}$ & $\begin{array}{l}0.35^{* * *} \\
(0.04)\end{array}$ \\
\hline Some college & $\begin{array}{l}0.46^{* * *} \\
(0.09)\end{array}$ & $\begin{array}{l}0.52^{\text {*** }} \\
(0.04)\end{array}$ & $\begin{array}{l}0.17^{* *} \\
(0.10)\end{array}$ & $\begin{array}{l}0.33^{* * *} \\
(0.06)\end{array}$ \\
\hline College degree & $\begin{array}{l}0.77^{* * *} \\
(0.10)\end{array}$ & $\begin{array}{l}0.70^{* * *} \\
(0.05)\end{array}$ & $\begin{array}{c}0.05 \\
(0.04)\end{array}$ & $\begin{array}{l}0.51^{* * *} \\
(0.07)\end{array}$ \\
\hline Advanced degree & $\begin{array}{l}0.89^{* * *} \\
(0.13)\end{array}$ & $\begin{array}{l}0.57^{* * *} \\
(0.07)\end{array}$ & $\begin{array}{l}0.16^{*} \\
(0.10)\end{array}$ & $\begin{array}{l}0.30^{* *} \\
(0.10)\end{array}$ \\
\hline \multicolumn{5}{|l|}{ Respondent's Education } \\
\hline High school & - & - & $\begin{array}{l}0.41^{\text {*** }} \\
(0.04)\end{array}$ & $\begin{array}{l}0.18^{* *} \\
(0.06)\end{array}$ \\
\hline Some college & - & - & $\begin{array}{l}0.42^{* * *} \\
(0.05)\end{array}$ & $\begin{array}{l}0.47^{* * *} \\
(0.06)\end{array}$ \\
\hline College degree & - & - & $\begin{array}{l}0.61^{* * *} \\
(0.06)\end{array}$ & $\begin{array}{l}1.03^{* * *} \\
(0.07)\end{array}$ \\
\hline Advanced degree & - & - & $\begin{array}{l}0.40^{* * *} \\
(0.06)\end{array}$ & $\begin{array}{l}0.97^{* * *} \\
(0.07)\end{array}$ \\
\hline \multicolumn{5}{|c|}{ Intergenerational Financial Transfers } \\
\hline Ever inherited & - & - & $\begin{array}{l}0.07^{* *} \\
(0.03)\end{array}$ & $\begin{array}{l}0.30^{* * *} \\
(0.03)\end{array}$ \\
\hline Amount inherited & - & - & $\begin{array}{l}0.01^{* * *} \\
(0.001)\end{array}$ & $\begin{array}{c}0.01^{* * *} \\
(0.001)\end{array}$ \\
\hline Received a trust fund & - & - & $\begin{array}{l}0.20^{* * *} \\
(0.07)\end{array}$ & $\begin{array}{l}0.56^{\text {*** }} \\
(0.06)\end{array}$ \\
\hline
\end{tabular}

these investments varies dramatically with resources, both in childhood and in adulthood, and other demographic traits.

The second and third models in Table 3 report the results of logistic regression equations that reveal that people with more siblings are less likely to own either a home or stocks as adults. There are at least two reasons for this finding. First, people from 
(Table 3, continued)

\begin{tabular}{|c|c|c|c|c|}
\hline Variable & $\begin{array}{c}\text { Received a } \\
\text { Trust Account }\end{array}$ & $\begin{array}{c}\text { Ever } \\
\text { Inherited }\end{array}$ & $\begin{array}{l}\text { Own } \\
\text { a Home }\end{array}$ & $\begin{array}{l}\text { Own } \\
\text { Stocks }\end{array}$ \\
\hline \multicolumn{5}{|l|}{ Controls } \\
\hline Black & $\begin{array}{l}-0.55^{* * *} \\
(0.11)\end{array}$ & $\begin{array}{c}-0.79^{* * *} \\
(0.04)\end{array}$ & $\begin{array}{l}-0.96^{* * *} \\
(0.05)\end{array}$ & $\begin{array}{c}-0.25^{* * *} \\
(0.07)\end{array}$ \\
\hline Hispanic & $\begin{array}{c}-0.10 \\
(0.13)\end{array}$ & $\begin{array}{l}-0.90^{* * *} \\
(0.05)\end{array}$ & $\begin{array}{l}-0.46^{* * *} \\
(0.07)\end{array}$ & $\begin{array}{c}-0.35^{* * *} \\
(0.08)\end{array}$ \\
\hline Age & $\begin{array}{c}0.01 \\
(0.01)\end{array}$ & $\begin{array}{l}0.01^{* * *} \\
(0.00)\end{array}$ & $\begin{array}{l}0.13^{* * *} \\
(0.00)\end{array}$ & $\begin{array}{l}0.04^{* * *} \\
(0.00)\end{array}$ \\
\hline Male & $\begin{array}{c}0.13 \\
(0.05)\end{array}$ & $\begin{array}{l}-0.20^{* * *} \\
(0.02)\end{array}$ & $\begin{array}{c}-0.11^{\text {*** }} \\
(0.03)\end{array}$ & $\begin{array}{l}0.15^{* * *} \\
(0.03)\end{array}$ \\
\hline \multicolumn{5}{|l|}{ Family Religion } \\
\hline Jewish & $\begin{array}{l}0.48^{* *} \\
(0.16)\end{array}$ & $\begin{array}{l}1.53^{* * *} \\
(0.14)\end{array}$ & $\begin{array}{c}-0.31^{*} \\
(0.14)\end{array}$ & $\begin{array}{c}0.28^{* *} \\
(0.13)\end{array}$ \\
\hline Catholic & $\begin{array}{c}-0.02 \\
(0.06)\end{array}$ & $\begin{array}{l}0.29^{* * *} \\
(0.02)\end{array}$ & $\begin{array}{c}0.07 \\
(0.03)\end{array}$ & $\begin{array}{l}0.26^{* * *} \\
(0.04)\end{array}$ \\
\hline Episcopalian & $\begin{array}{l}0.54^{* * *} \\
(0.14)\end{array}$ & $\begin{array}{l}1.20^{* * *} \\
(0.09)\end{array}$ & $\begin{array}{l}-0.22 \\
(0.11)\end{array}$ & $\begin{array}{c}0.05 \\
(0.10)\end{array}$ \\
\hline Protestant & $\begin{array}{c}0.24 \\
(0.08)\end{array}$ & $\begin{array}{l}0.27^{* * *} \\
(0.03)\end{array}$ & $\begin{array}{c}-0.11^{*} \\
(0.05)\end{array}$ & $\begin{array}{c}0.07 \\
(0.05)\end{array}$ \\
\hline \multicolumn{5}{|l|}{ Family Structure at Age 14} \\
\hline Stepparent family & $\begin{array}{c}0.00 \\
(0.10)\end{array}$ & $\begin{array}{c}0.12 \\
(0.13)\end{array}$ & $\begin{array}{c}-0.13^{* *} \\
(0.05)\end{array}$ & $\begin{array}{c}-0.10 \\
(0.06)\end{array}$ \\
\hline Single-parent family & $\begin{array}{l}-0.32^{* * *} \\
(0.08)\end{array}$ & $\begin{array}{c}0.22 \\
(0.23)\end{array}$ & $\begin{array}{c}-0.23^{* * *} \\
(0.05)\end{array}$ & $\begin{array}{c}-0.20^{* * *} \\
(0.05)\end{array}$ \\
\hline \multicolumn{5}{|l|}{ Adult Family } \\
\hline Married & $\begin{array}{c}0.12 \\
(0.06)\end{array}$ & $\begin{array}{c}0.04 \\
(0.03)\end{array}$ & $\begin{array}{l}1.82^{* * *} \\
(0.03)\end{array}$ & $\begin{array}{l}0.59^{* * *} \\
(0.04)\end{array}$ \\
\hline Ever divorced & $\begin{array}{c}-0.04 \\
(0.10)\end{array}$ & $\begin{array}{c}-0.16^{* *} \\
(0.03)\end{array}$ & $\begin{array}{c}0.12^{*} \\
(0.05)\end{array}$ & $\begin{array}{l}0.17^{* *} \\
(0.06)\end{array}$ \\
\hline Ever had children & $\begin{array}{c}0.34^{*} \\
(0.07)\end{array}$ & $\begin{array}{l}0.15^{* * *} \\
(0.03)\end{array}$ & $\begin{array}{l}0.20^{* * *} \\
(0.04)\end{array}$ & $\begin{array}{c}0.09^{*} \\
(0.05)\end{array}$ \\
\hline Number of children & $\begin{array}{c}0.00 \\
(0.03)\end{array}$ & $\begin{array}{l}0.08^{* * *} \\
(0.01)\end{array}$ & $\begin{array}{l}0.04^{* *} \\
(0.02)\end{array}$ & $\begin{array}{l}-0.08^{* * *} \\
(0.02)\end{array}$ \\
\hline Divorced $\times$ had children & $\begin{array}{c}-0.07 \\
(0.05)\end{array}$ & $\begin{array}{c}0.01 \\
(0.02)\end{array}$ & $\begin{array}{l}-0.13^{* * *} \\
(0.03)\end{array}$ & $\begin{array}{l}-0.14^{* * *} \\
(0.04)\end{array}$ \\
\hline \multicolumn{5}{|l|}{ Adult Resources } \\
\hline Family income & $\begin{array}{c}0.01 \\
(0.01)\end{array}$ & $\begin{array}{c}0.01 \\
(0.01)\end{array}$ & $\begin{array}{l}0.01^{* * *} \\
(0.001)\end{array}$ & $\begin{array}{l}0.01^{\text {*** }} \\
(0.001)\end{array}$ \\
\hline Entrepreneurial income & $\begin{array}{c}0.05 \\
(0.09)\end{array}$ & $\begin{array}{c}0.34 \\
(0.04)\end{array}$ & $\begin{array}{c}0.31 \\
(0.06)\end{array}$ & $\begin{array}{c}0.00 \\
(0.07)\end{array}$ \\
\hline-2 Log-Likelihood & $14,646^{* * *}$ & $75,629^{* * *}$ & $43,059^{* * *}$ & $32,510^{* * *}$ \\
\hline
\end{tabular}

Notes: Standard errors are in parentheses. Sample size refers to the total number of respondents included, rather than the number of person-years. Also controlled, but not displayed, were indicators of whether the respondent was born outside the United States, whether either parent was born outside the United States, the number of weeks worked by the spouse, urban residence, and region of residence.

${ }^{*} p<.05 ;{ }^{* *} p<.01 ;{ }^{* * *} p<.001$

smaller families are more likely to receive an inheritance, and the inheritance they receive is likely to be greater than what they would have received if their family had been larger. Inherited wealth, even a small amount of it, can enable educational attainment, 
reduce the need to acquire debt for educational and other expenses in young adulthood, and provide a financial basis that both reduces the expenses associated with life transitions and is a source of capital for investment. Each of these outcomes, in turn, can significantly increase the recipient's ability to purchase a home and to invest in stocks. Second, people from smaller families enjoy greater financial and nonmaterial wealth in childhood that can also be translated into more resources in adulthood. In models not reported, I omitted the exogenous controls for inheritance, and the sibling result was strong. In Table 3, Models 2 and 3, I included the controls for the amount of wealth inherited to isolate the effect of siblings on the ownership of these assets. The effect of sibship size is greater when inheritance is not controlled (models not displayed). Thus, the results reported in Table 3 provide some evidence that the relationship between additional siblings and the ownership of a home or stocks operates through a reduction in the availability of other (noninheritance) resources that can be diluted by family size.

\section{CONCLUSIONS}

This research explored the relationship between sibship size (number of siblings) and adults' wealth accumulation. I observed that recent growth in the inequality of wealth has been alarming, but little is known about families' asset-accumulation patterns that underlie this inequality. Research on wealth has often referred to childhood family behaviors and processes, including family size, as a likely source of differences, but these ideas had not previously been explored in any depth. In this article, I argued that siblings decrease the total wealth in adulthood by diluting resources available to each child in the family of origin. As a result, sibship size decreases both educational attainment and direct intergenerational transfers of financial resources. During childhood, additional siblings strain the material resources available for education, books and magazines, computer resources, music and dance lessons, and travel. Additional siblings may also dilute the nonmaterial resources that parents devote to their children, including encouragement, educational experiences, and intervention. In addition, more children reduce parental savings, inter vivos transfers, and the wealth that is available to bequeath at the end of the parents' lives. Decreased educational attainment and intergenerational resource transfers, in turn, alter financial behavior and saving trajectories. As a result, those from larger families accumulate smaller portfolios throughout their lives.

I examined the relationship between family background and adults' wealthaccumulation patterns using the NLS-Y79 and found considerable support for my arguments. There was a strong negative association between sibship size and overall wealth in adulthood. Consistent with the mechanisms I proposed, the effect of siblings was reduced when I controlled parents' financial resources and education. Similarly, controlling for the respondent's education and intergenerational financial transfers reduced the effect of siblings on wealth even further. Finally, controlling for financial behavior and saving trajectories also reduced - but did not erase - the effect of siblings on wealth in adulthood. I proposed that siblings continued to affect wealth because I was not able to measure the effects of the respondents' social connections or parents' nonmaterial resources. I also investigated the proposed mechanisms further by exploring the direct effect of siblings on the likelihood of receiving direct financial transfers from parents, including a trust (an inter vivos transfer) and an inheritance. In both cases, the effect of siblings was strong and negative. Finally, I explored the direct effect of siblings on the likelihood of adults' financial behaviors, including stock ownership and homeownership. Again the effect of sibship size was strong and negative, even in the presence of the proposed controls, such as childhood family resources, parents' education, respondents' educational attainment, and intergenerational financial transfers.

An important caveat is that the sample I used to test these ideas was born between 1957 and 1964 and was 35-43 years old in 2000. The cohort is the later stage of the baby 
boom, a cohort in which more women work, educational attainment is higher than for earlier cohorts, and families postpone fertility and remain childless at high rates. These factors have allowed this cohort to accumulate considerably more assets than previous generations (Keister and Deeb-Sossa 2000), and it is possible that a cohort effect produced some of the results evident in the findings presented here. However, the large number of control variables included in the models should account for most of the otherwise unobserved cohort effect. Moreover, this group is in the early stages of accumulating wealth, suggesting that the wealth values I used are conservative estimates of their potential total lifetime assets.

These findings provide additional support for the idea that sibship size reduces attainment. Previous research on the dilution of resources has been largely limited to studies of educational attainment. Although the negative relationship between sibship size and educational outcomes in adulthood has been one of the most persistent findings in the education literature (Blake 1989; Downey 1995), the debate over the conditions under which the relationship holds and the reason for the effect has continued (Downey et al. 1999; Guo and VanWey 1999). Critics have charged that a spurious relationship between unobserved family traits accounts for the relationship, and, of course, siblings may provide certain advantages (e.g., emotional support and financial assistance). Yet proponents of the resource-dilution approach have successfully defended the argument that the dilution of resources largely accounts for the negative relationship between sibship size and educational attainment. My results extend the discussion in this area beyond the study of education and demonstrate that additional siblings do, indeed, reduce the financial resources that parents transfer directly to their children in the form of inheritance. They also suggest that sibship size affects other aspects of the accumulation of wealth, including the types of assets that people eventually acquire and the overall level of wealth they eventually attain.

Perhaps most important, these findings underscore the importance of family processes in the accumulation of wealth. Recent research has documented extreme inequalities in wealth ownership, but the processes by which these inequalities develop and are perpetuated have received relatively little attention. Inherited wealth certainly accounts for much of the wealth that is acquired, particularly by the extremely wealthy, but inheritance does not explain even the majority of the variation in wealth across families. Researchers have pointed to the importance of family processes, but data limitations have prevented systematic analyses of the relationship between processes in the family of origin and wealth outcomes in adulthood. The results I presented here provide support for arguments that family traits, particularly family size in childhood, can either facilitate or impede wealth accumulation, both early in life and throughout the life course. These findings suggest that efforts to reduce inequality in wealth ownership may be most effective if they seek to reduce the effect of deprivation early in life.

\section{REFERENCES}

Biblarz, T.J. and A.E. Raftery. 1993. "The Effects of Family Disruption on Social Mobility." American Sociological Review 58:97-109.

Biblarz, T.J, A.E. Raftery, and A. Bucur. 1997. "Family Structure and Mobility." Social Forces 75:1319-41.

Blake, J. 1981. "Family Size and the Quality of Children.” Demography 18:421-42. 1989. Family Size and Achievement. Berkeley: University of California Press.

Chiteji, N.S. and F.P. Stafford. 1999. "Portfolio of Choices of Parents and Their Children as Young Adults: Asset Accumulation by African-American Families." American Economic Review 89:377-80.

Cohen, B.P. 1989. Developing Sociological Knowledge: Theory and Method. Chicago: NelsonHall. 
Conley, D. 1999. Being Black, Living in the Red: Race, Wealth and Social Policy in America. Berkeley: University of California Press.

Davies, J.B. 1982. "The Relative Impact of Inheritance and Other Factors on Economic Inequality." Quarterly Journal of Economics 97:471-98.

Davies, J.B. and A.F. Shorrocks. 1999. "The Distribution of Wealth." Pp. 605-75 in Handbook of Income Distribution, Volume 1, edited by A.B. Atkinson and F. Bourguignon. New York: Elsevier Science.

Downey, D.B. 1995. "When Bigger Is Not Better: Family Size, Parental Resources, and Children's Educational Performance." American Sociological Review 60:746-61.

Downey, D.B., B. Powell, L.C. Steelman, and S. Pribesh. 1999. "Much Ado About Siblings: Change Models, Sibship Size, and Intellectual Development (Comment on Guo and VanWey)." American Sociological Review 64:193-98.

Dynan, K.E. 1993. "The Rate of Time Preference and Shocks to Wealth: Evidence From Panel Data." Working Paper, No. 134. Washington, DC: Board of Governors, Federal Reserve System.

Eggebeen, D.J. and D.T. Lichter. 1991. "Race, Family Structure, and Changing Poverty Among American Children." American Sociological Review 56:801-17.

Friedman, D., M. Hechter, and S. Kanazawa. 1994. "A Theory of the Value of Children.” Demography 31:375-401.

Guo, G. and L.K. VanWey. 1999. "Sibship Size and Intellectual Development: Is the Relationship Causal?" American Sociological Review 64:169-87.

Hao, L. 1996. "Family Structure, Private Transfers, and the Economic Well-being of Families With Children." Social Forces 75:269-92.

Hill, C.R. and F.P. Stafford. 1978. "Intergenerational Wealth Transfers and the Educational Decisions of Male Youth: An Alternative Interpretation." Quarterly Journal of Economics 92:515-20.

Judge, G.G., W.E. Griffiths, R.C. Hill, and T.-C. Lee. 1985. The Theory and Practice of Econometrics. 2nd ed. New York: John Wiley and Sons.

Juster, T.F. and K.A. Keuster. 1991. "Differences in the Measurement of Wealth, Wealth Inequality and Wealth Composition Obtained From Alternative U.S. Wealth Surveys." Review of Income and Wealth 37:33-62.

Juster, T.F., J.P. Smith, and F. Stafford. 1999. "The Measurement and Structure of Household Wealth." Labour Economics 6:253-75.

Keister, L.A. 2000a. "Race and Wealth Inequality: The Impact of Racial Differences in Asset Ownership on the Distribution of Household Wealth." Social Science Research 29:477-502.

. 2000b. Wealth in America. New York: Cambridge University Press.

- Forthcoming. "Religion and Wealth Accumulation." Social Forces.

Keister, L.A. and N. Deeb-Sossa. 2000. "Are Baby Boomers Richer Than Their Parents? Intergenerational Patterns of Wealth Ownership in the United States." Journal of Marriage and the Family 62:569-79.

Keister, L.A. and S. Moller. 2000. "Wealth Inequality in the United States." Annual Review of Sociology 26:63-81.

Kennickell, A.B. 2000. "An Examination of Changes in the Distribution of Wealth From 1989-1998: Evidence From the Survey of Consumer Finances.” Working Paper. Washington, DC: Federal Reserve Board.

Kennickell, A.B. and M. Starr-McCluer. 1994. "Changes in Family Finances From 1989 to 1992: Evidence From the Survey of Consumer Finances.” Federal Reserve Bulletin October:861-82.

Kennickell, A.B., M. Starr-McCluer, and A.E. Sunden. 1997. "Family Finances in the U.S.: Recent Evidence From the Survey of Consumer Finances." Federal Reserve Bulletin January:1-24.

McLanahan, S.S. 1985. "Family Structure and the Reproduction of Poverty." American Journal of Sociology 90:873-901.

McLanahan, S.S. and G.D. Sandefur. 1994. Growing Up With a Single Parent: What Hurts, What Helps. Cambridge, MA: Harvard University Press. 
McNamee, S.J. and J.R.K. Miller. 1998. "Inheritance and Stratification." Pp. 193-213 in Inheritance and Wealth in America, edited by J.R.K. Miller and S.J. McNamee. New York: Plenum Press.

Mechanic, D. and S. Hansell. 1989. "Divorce, Family Conflict, and Adolescents' Well-being." Journal of Health and Social Behavior 30:105-16.

Norris, F. 1996. "Flood of Cash to Mutual Funds Helped Fuel '95 Bull Market." New York Times, January 1, p. A1.

Oliver, M.O. and T.M. Shapiro. 1995. Black Wealth/White Wealth. New York: Routledge.

Popper, K.R. 1965. Conjectures and Refutations: The Growth of Scientific Knowledge. New York: Harper and Row.

Sandefur, G.D. and T. Wells. 1999. "Does Family Structure Really Influence Educational Attainment?" Social Science Research 28:331-57.

Spilerman, S. 2000. "Wealth and Stratification Processes." Annual Review of Sociology 26:497-524.

Stafford, F.P. 1996. "Early Education of Children in Families and Schools." Pp. 972-80 in Household and Family Economics: Recent Economic Thought, edited by P. Menchik. Boston: Kluwer Academic.

Teachman, J.D. 1987. "Family Background, Educational Resources, and Educational Attainment." American Sociological Review 52:548-57.

Thomson, E., T.L. Hanson, and S.S. McLanahan. 1994. "Family Structure and Child Well-being: Economic Resources vs. Parental Behaviors." Social Forces 73:221-42.

Wolff, E.N. 1995. "The Rich Get Increasingly Richer: Latest Data on Household Wealth During the 1980s." Pp. 33-68 in Research in Politics and Society, Vol. 5, edited by R.E. Ratcliff, M.L. Oliver, and T.M. Shapiro. Greenwich, CT: JAI Press.

_ 1998. "Recent Trends in the Size Distribution of Household Wealth." Journal of Economic Perspectives 12:131-50.

Wu, L.L. 1996. "Effects of Family Structure and Income on Risks of Premarital Birth." American Sociological Review 61:386-406.

Zagorsky, J.L. 1997. NLS-Y79 Users' Guide. Pp. 135-56, Vol. 45. Columbus: Center for Human Resource Research, The Ohio State University. - 1999. "Young Baby Boomers' Wealth." Review of Income and Wealth 45:135-56. 